International Journal of Social Sciences and Humanities
Available online at http://sciencescholar.us/journal/index.php/ijssh
Vol. 3 No. 2, August 2019, pages: $250 \sim 260$
e-ISSN: 2550-7001, p-ISSN: 2550-701X
https://doi.org/10.29332/ijssh.v3n2.324

\title{
Meaning of Cost Components and Cost Magnitude Determining Tender Prices: A Study on CV. RG
}

\author{
CrossMark \\ Ni Putu Pradnyani Paramita a ${ }^{\text {, I Putu Sudana }}{ }^{\mathrm{b}}$, I.G.A.N. Budiasih ${ }^{\mathrm{c}}$, Herkulanus Bambang Suprasto ${ }^{\mathrm{d}}$ \\ Article history: Received 09 December 2018, Accepted: 30 April 2019, Published: 27 August 2019

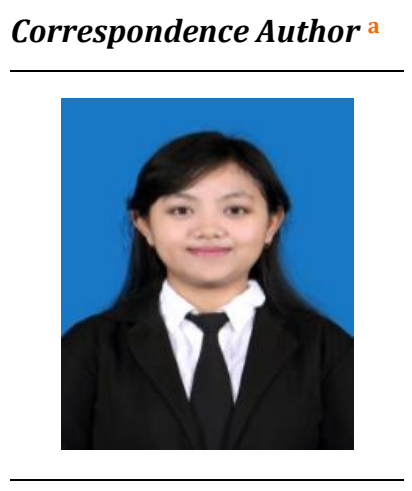 \\ Keywords \\ interpretative; \\ meaning; \\ phenomenology analysis; \\ schutz phenomenology; \\ tender offer;

\begin{abstract}
The cost was the basis for management in determining the selling price of a product or service. In construction service companies, the cost determining is important. It will affect the value of the tender proposal submitted to get the job. CV. RG is a construction service company provides services in the civil and building fields. CV. RG, of course, has often participated in tenders. The problem is the company often suffer losses. The company's success rate is still relatively low. The company participates in a tender, costs, and efforts arise in preparing the tender. In conducting costing, there are at least two aspects must be considered. It is namely the cost component and cost magnitude. This study uses a phenomenological approach to gain an understanding of decision holders about a reality based on experience. The interpretative phenomenology method is suitable to be used due to the researcher wants to reveal and understand how the decision holders. CV. RG means cost component and cost magnitude is in the process of price-determining the tender proposal. The results of the research analysis showed that in determining the cost component. The informant felt complicated due to the situation at hand. The dilemma feelings also accompanied the informants in determining the cost magnitude of the tender proposal. The meaning of this informant can also be explained because of motives and in order to motives that underlie the informant actions.
\end{abstract}

e-ISSN: 2550-7001, p-ISSN: 2550-701X ๑ Copyright 2019. The Author.

SS Journals Published by Universidad Técnica de Manabí. This is an open-access article under the CC BY-SA 4.0 license

(https://creativecommons.org/licenses/by-sa/4.0/) All rights reserved.

a Udayana University, Denpasar, Indonesia

b Udayana University, Denpasar, Indonesia

c Udayana University, Denpasar, Indonesia

d Udayana University, Denpasar, Indonesia 


\section{Contents}

Abstract

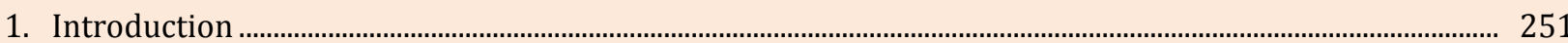

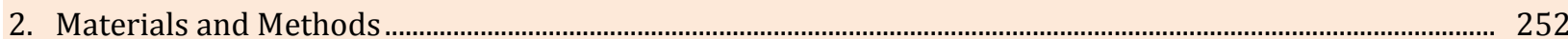

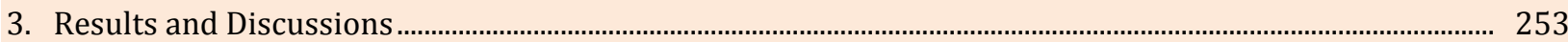

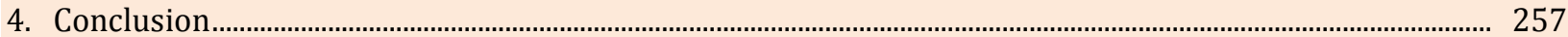

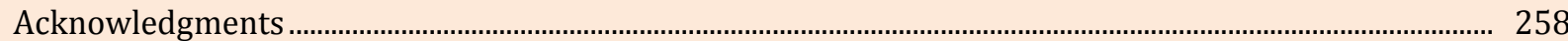

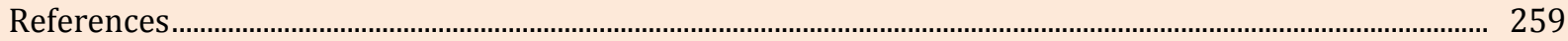

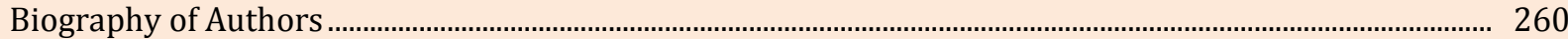

\section{Introduction}

Costs are the basis for management in determining the selling price of a product or service. Cost is a factor within the company will affect the selling price other than the quality level factor of the goods or services produced. The factors outside the company are factors that are not costs, such as the economic state, market demand, and supply, actions or reactions of competitors, government supervision, and others. The two factors will greatly influence the determination of selling prices. In determining the selling price with the concept of costs, costs can provide information on the lower limit of a price. It must be determined by the company for a product or service.

Determining the selling price of a product or service is an important management decision. The price set must be able to cover all costs to get the profit expected by the company. Choosing the most appropriate price for the product or service produced is a manager's decision. It is quite difficult. Due to the price-setting affects company development. According to Horngren et al., (2012), there are three main things that affect sales price decisions. They are namely customers, competitors, and costs. In construction service companies, the cost determining is important because it will affect the value of the tender proposal submitted to get the job.

CV. RG is a construction service company. It provides services in the civil and building fields. As a company, they always associated with government projects. It is very dependent on tenders to obtain projects. CV. RG, of course, has often participated in tenders. However, the problem is companies often suffer losses. The company's success rate is still relatively low. If a company participates in a tender, costs, and efforts arise in preparing the tender. Thus, if the company loses when it follows the tender. There will be wasted costs and efforts. These costs and wasted efforts can be a significant burden on the company.

In conducting costing, there are at least two aspects must be considered. They are namely the cost component and cost magnitude. Cost component is related to what costs will be included when calculating the selling price. The cost magnitude considers the number of costs. It can be borne by the company when setting the selling price. This also applies to determine the price of a tender proposal to a contracting company. Cost component and cost magnitude can be very subjective for each decision holder, resulting in tender proposals with different costs. Shrestha et al., (2013), stated that cost magnitude in contractor companies is influenced by project size, project complexity, and schedule.

Subjectivity to the cost component and cost magnitude aspects experienced by the decision holders is strongly influenced by their beliefs. It can be explained by the theory of planned behavior (TPB). It states humans are rational creatures and use information that is possible for them systematically. According to Ajzen (1991), the main factor in TPB is the intention of individuals to show the behavior given. Intention is assumed to capture motivational factors that influence behavior, an indication of how someone wants to try, how much effort they plan in urging, in order to show their behavior. The subjectivity of the decision holders in CV. RG in determining the tender proposal is strongly influenced by the meaning of the cost component and cost magnitude itself which then affects the price of the company's tender proposal. Thus, a study of how the tender proposal decision-makers in CV. RG means that aspects of cost component and cost magnitude are important to do.

Smith \& Osborn (2015), interpretative phenomenology analysis (IPA) is a qualitative approach aims to provide a detailed examination of the personal experiences they have undertaken. In IPA, the researchers try

Paramita, N. P. P., Sudana, I. P., Budiasih, I., \& Suprasto, H. B. (2019). Meaning of cost components and cost magnitude determining tender prices: A study on CV. RG. International Journal of Social Sciences and Humanities, 3(2), 250-260. https://doi.org/10.29332/ijssh.v3n2.324 
to understand participants who try to understand what is happening to them. IPA recognizes the phenomenological commitment to examine a topic, as far as possible, in its own way (Smith \& Eatough, 2008). IPA involves an interpretative process on the part of researchers and participants. IPA requires intensive qualitative analysis of participant's personal details. Therefore, the most common data collection methods are in-depth interviews and semi-structured. IPA is usually carried out at relatively small sample sizes sufficient to realize IPA (Smith, 2011; Putri \& Sujana, 2018).

This study uses a phenomenological approach to gain an understanding of decision holders about a reality based on experience. The interpretative phenomenology method is suitable to be used. Due to the researcher wants to reveal and understand how the decision holders in the CV. RG means cost component and cost magnitude in the process of determining the price of a tender proposal. Interpretative phenomenology is expected to be able to provide answers to research problems. It is centered on two aspects namely (1) how the drafting and decision-making proposals interpret the cost aspects of determining the tender price; and (2) under what conditions/situations they obtain such an interpretation.

Appropriate cost determination is important in implementing an efficient inventory control system (Berling, 2008). Determination of costs is also important in determining pricing strategy. Ingenbleek (2015), suggested pricing strategies for sustainable products enable producers to minimize the potential competitive losses they suffer. Due to they have to cover additional costs for sustainability. The study revealed six different strategies built on three mechanisms: cost-based prices combined with price equity, increasing the desire to pay through perceived quality, and price stability compensated for scale or learning effect.

Khanh et al., (2018), determining a reasonable selling price to produce business efficiency is one of the most important issues in corporate governance. When making pricing decisions, managers rely on a variety of sources of information but must not ignore cost information. Fixed costs can be a sunk cost. It can affect competitive pricing decisions. Increasing the number of fixed costs can turn profits into losses and affect short-term pricing decisions (Tversky \& Kahneman, 1991).

Nimer et al., (2015), stated pricing decisions cannot be made in a vacuum. However, it must consider the impact on the nature of the products and services offered and the extent to which they can be promoted. It can be seen that in making a pricing decision, in addition to costing must also consider other impacts of the products or services we offer. Research on cost with a phenomenological approach has not been done more. Research with the phenomenology of Komalasari et al., (2019), for example, which tries to uncover how Balinese career-woman accountants carry out harmonization of accountability practices. This study reveals the meaning of the practice of accountability for the knowledge and understanding of Balinese career women is known to be derived from the values of indigenous philosophies, cultures, and religions are in their environment.

Having seen the phenomena that arise in the company, the researchers feel interested to further study the phenomena that occur. This research is important because the cost component and cost magnitude have an important role in determining the price of a tender proposal submitted in a contracting company. A tender proposal is key to getting a job for a contractor. This research is expected to be able to contribute to thinking about the importance of cost components and cost magnitude in determining tender prices. The research is expected to contribute to the CV. RG when considering tender pricing.

\section{Materials and Methods}

This study uses primary data obtained directly from the research location. Data is obtained direct interviews with research informants namely the decision-makers of the tender. Secondary data is also needed is the company documents in the form of tender documents and tender lists that are followed by the company.

\section{Methods of data collection and processing}

The researcher became a research instrument to collect data. Data collection is done by interview and observation. The interview is semi-structured. It means the researcher has made the initial questions. However, it can be developed during the interview. As a guiding question when conducting interviews is how 
the informants interpret the cost component and cost magnitude in their experience determining the price of the tender proposal and under what circumstances the informants interpret it as like. Observation is done by coming directly to the company to see the documents needed. After the interview is done, the next step is to process the recording of the interview to be used as an interview manuscript. After that, an interview analysis manuscript is carried out in the form of thematic analysis.

\section{Method of data presentation and analysis}

Interview manuscripts were analyzed using IPA. In general, IPA provides flexible guidelines that can be adopted by researchers based on research objectives. In this study, adopting IPA according to Pietkiewicz \& Smith (2014), consists of four stages, namely multiple reading and making notes, transforming notes into emergent themes, and seeking relationships and clustering themes, and writing up. Then, the results of the analysis are interpreted using the Schutz phenomenology approach. Presentation of the results of data analysis will be presented like any other qualitative research in the form of narrative texts.

\section{Results and Discussions}

\section{Access and Relationship}

This research will be meaningless if the informant does not want to open up with the researcher. As we already know in qualitative research the closeness to a research location is the key to conducting research. The researchers know this company when researchers are still studying S1 (bachelor degree) then doing research in the CV. RG. Wherein, the owner is an acquaintance of the researcher's parents. The informants used in this study were the tender decision holders. The two people are KP as the owner of the company and the US as the director and technical person in charge. In getting to know the two in this study, it is not difficult for researchers because researchers and informants have known each other before.

\section{Research ethics in collecting data}

In this study, researchers as best as possible to maintain ethics during the research process. Ethics does not only take place during interviews but also includes communication. During communication to deepen research, researchers as best as possible not to force to ask questions when there are things that are not clear if the informant is felt in a busy condition. When conducting interviews the researchers also tried not to interrupt every informant's conversation. Thus, the informant felt comfortable telling stories. In addition, in order to maintain the confidentiality of informants, researchers disguised the company name and informant name in the form of initials only. This is important because in some interview passages there are statements that might be offensive to others.

\section{Validity data}

Shinebourne (2011), IPA commitment is demonstrated throughout the research process, from selecting samples that may require persistence in accessing potential participants, through a commitment to engaging with participants with sensitivity and respect and commitment to present a detailed and thorough analysis. Smith \& Osborn (2015), suggested several criteria for assessing internal validity and the reliability of qualitative research. There are two important criteria in assessing the validity and reliability of qualitative research, namely internal coherence and presentation of evidence. In this study, in order to ensure trust in the study, interview manuscripts were shown to participants to ensure that the compiled manuscripts reflected appropriate meanings. At that time, the informant also gave explanations again in several sections to increase the understanding of researchers.

Paramita, N. P. P., Sudana, I. P., Budiasih, I., \& Suprasto, H. B. (2019). Meaning of cost components and cost magnitude determining tender prices: A study on CV. RG. International Journal of Social Sciences and Humanities, 3(2), 250-260. https://doi.org/10.29332/ijssh.v3n2.324 


\section{Steps on data sorting}

1) Multiple reading and making notes. In the early stages, it involves reading as close as possible to a number of manuscripts that are repeated. If you use an audio recording, it is also recommended to listen repeatedly. This helps the researcher to recall the atmosphere of the interview and the setting took place. Every reading and recording allows new insights to emerge. At this stage, researchers can take notes about their observations and illustrate interview experiences or other thoughts and comments.

2) Transforming notes into emergent themes. At this stage, the researcher is paying more attention to the notes given than the transcript. The aim is to transform notes into themes. The researchers formulate concise phrases that are slightly higher in the level of abstraction. It may be closer to psychological conceptualization. The transformation of the initial notes into themes was carried out throughout the interview manuscripts.

3) Seeking relationships and clustering themes. The next step is to look for relationships between themes, group them together based on conceptual equations, and provide each group with a descriptive table. Some themes may be issued at this stage if they do not fit the structure built in the study or have a weak evidence base. Grouping themes can be seen in the following Diagram 1 and Diagram 2:

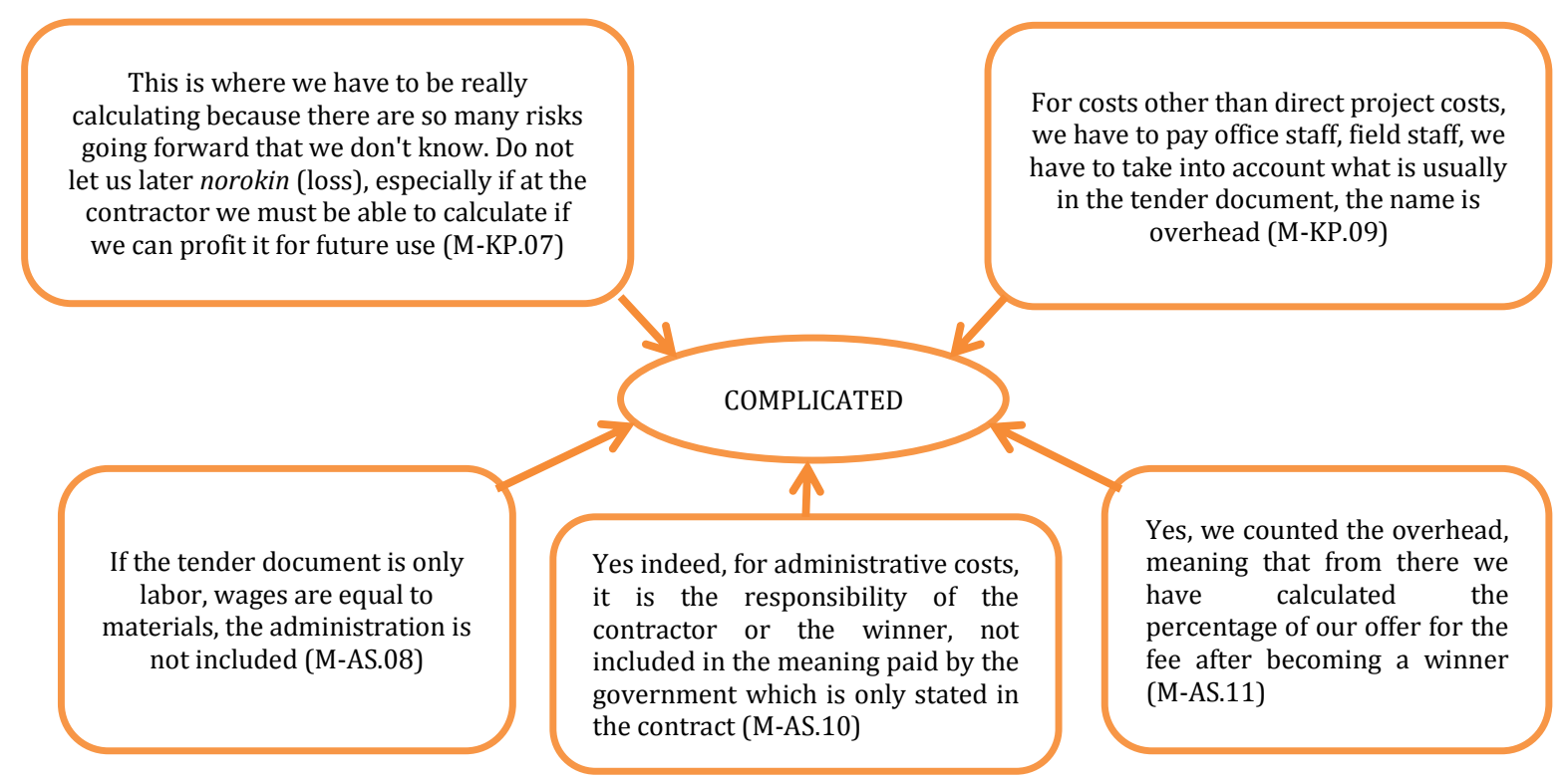

Diagram 1. Complicated feelings in determining cost components 


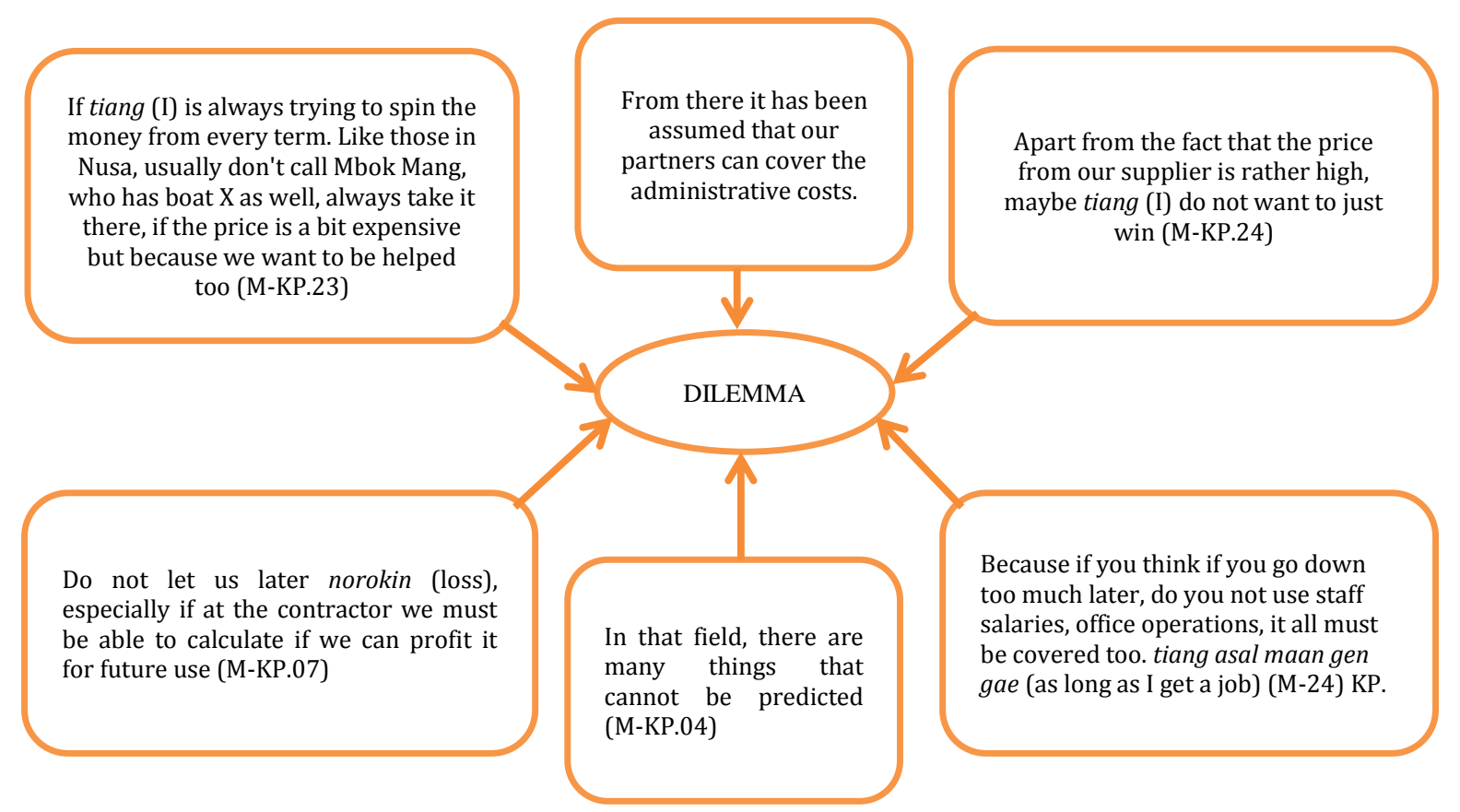

Diagram 2. Dilemma on determining cost magnitude

4) Writing Up. The analysis involves writing a narrative account of the research. This usually involves taking the themes identified in the final table and writing them down one by one. The theme table opens a persuasive account that explains to the reader the importance of the experiences discovered during the analysis process. The final writing includes the participant's account of his/her experience and the interpreter's interpretation.

\section{Informant Interpretation \\ Informant's perspective on determining cost components}

In determining the tender price, the informant will take into account the number of costs that will be incurred related to the project package that will be taken. Each project has its own RAB and the company must be able to calculate carefully. In fact on the CV. RG, there are costs cannot be included in the tender offer document. The costs entered by the informant are a direct cost component in the project. In making the tender offer, the informant must first pay attention to the HPS issued by the committee. This is based on information from US informants, unlike the following:

\footnotetext{
"If the tender document is only labor, the salary is equal to materials, the administration is not included" (M-AS.08)

"The conditions are indeed like that" (M-AS.09)

"Yes, for administrative costs, it is the responsibility of the contractor/winner, it is not included in the meaning paid by the government which is only stated in the contract" (M-AS.10)

A similar matter was also mentioned by KP informants regarding the cost components included in the tender proposal document:

"If the tender permitted by the government is the only cost, material costs are equal to labor costs. This is where we have to be really calculating because there are so many risks going forward that we don't know. We don't want to be norokin, especially if it's at the contractor, we have to be able to calculate if we can profit from it for the next year" (M-KP.07)
}

In making a tender offer, it turns out that administrative costs are not taken into account. This is in accordance with Latupeirissa (2009), indirect costs are not explicitly stated in the format of the fee offer

Paramita, N. P. P., Sudana, I. P., Budiasih, I., \& Suprasto, H. B. (2019). Meaning of cost components and cost magnitude determining tender prices: A study on CV. RG. International Journal of Social Sciences and Humanities, 3(2), 250-260. https://doi.org/10.29332/ijssh.v3n2.324 
letter. Administrative costs to support the implementation of the project are only calculated based on the contractor's estimate. Then, how much is the administration fee?

"There are administrative-related costs like we are obliged to register laborers joining BPJS, we have to pay whether we want it or not. If it has not been paid yet, we cannot sign the SPK, then we have to pay for collateral as well, material support, now we are all responsible contractors. Even though it is not included in the tender document, we must pay it all if we want to get the project" (M-KP.08)

If you look at what has been said, it appears that in determining the cost component is quite complicated. Determination of cost components by the informant cannot arbitrarily include indirect cost components. What is experienced by the informant becomes complicated because the determination of the cost component in addition to following existing rules, the informant must also not ignore the cost component that is indirect. The existence of indirect costs is then calculated from the overhead the company adds to each work item. "Yes, we counted the overhead, it means that from there, we have calculated the percentage of our bid for that fee after winning" (M-AS.11)

\section{Informant's perspective on determining cost magnitude}

Calculating the price of a tender proposal, it is no less important than the informant must determine the cost magnitude of the tender proposal. Each cost component has been determined by the informant, then the amount of the fee will be calculated in the tender proposal. The method used by the informant to determine the cost magnitude is as follows. "That, we must know first what is the price of the material that is roughly needed, then we try to find a foreman with a handyman if this brave project how much. After that, then we can predict how much we want to bargain for. Usually, tiang (I) also determine it" (M-KP.20). Aside from the information obtained by the informant, cost magnitude also pays attention to the experiences of fellow contractor informants.

"The other companies s/he can bargain for are many people who are maan gen gae (as long as they get a job), they don't know what the terrain is. High bargain, just so I can get a job. We as those who know the location, do not dare to be so. Many contractors do not know the location, as soon as new road projects get there and are shocked, how come this is how it is like that, no longer does it count at the beginning. Ngudiang nyemak gae maan tuyuh gen (for what taking work can only be a hassle), we don't want to be like that" (M-KP.22)

In determining tender prices, in addition to calculating estimated costs, it is also important to consider factors beyond costs. European Commission (1998), stated that the cost of a project is highly dependent on various factors. These factors such as project specifications, location, the form of procurement/contract, location characteristics, new build or improvement, tax liabilities, timescale, and inflation. In addition to the factors mentioned above, the informant also has other considerations in determining the cost magnitude:

"If tiang (I) am always trying to spin the money from every term. Like those in Nusa, usually don't call Mbok Mang, who has boat X too, always take it there, if the price is a bit expensive but because we want to be helped too" (M-KP.23) "Another consideration, tiang (I) do not want to be like the other jor-joran (drastically) reduce the price like that huh, because if you think if you go down too much later do not use staff salaries, office operations, it all must be covered too. I don't want asal maan gen gae (just get a job)" (M-KP.24)

The statement conveyed by the informant refers to the dilemma experienced by the informant when determining the cost magnitude because the determination of the cost magnitude is very influential on the tender price. The dilemma faced by the informants is related to the desire to keep also maintaining good relations with suppliers who have helped so far. However, on the other hand, the tender price set by the company is higher. 


\section{Researcher interpretation}

From the results of the interviews, the informants then grouped themes related to understanding cost components and cost magnitude. Using the Schutz phenomenology (Schutz, 1967), we can see the motives that underlie the informant's understanding in each theme:

1) Informant's perspective on determining cost components. In this theme, the informant explained the determination of the cost component when calculating the tender price. For informants the determination of the cost component becomes complicated by the situation there are rules that limit it. The complicated feeling felt by the informants is because the cost components allowed in the tender are only direct, whereas, in reality, indirect costs also have an important role for the informant. regarding Schutz's phenomenology approach, it can be seen that the motives that influence informants in interpreting cost components are:

a) Because motives. In interpreting the cost component of the informant is influenced by the experience of the tenders that have been passed and the rules set by the tender committee. In covering indirect costs, the informant calculates from overhead. This overhead is calculated by the informant also based on the informant's past experiences.

b) In order to motives. Even though the informants were complicated in determining the cost component, the informants still had the same goal of winning the tender. Regarding the predetermined cost component, the informant wants to be able to win the tender that was followed.

2) Informant's perspective on determining cost magnitude. Determination of cost magnitude by the informant caused a feeling of a dilemma. This dilemma is caused by the informant having other considerations in determining the cost magnitude itself. The cost magnitude by the informant is also based on the desire of the informant to maintain good relations with suppliers who have provided payment relief so far. However, then, it is the cause of the high price of the proposed tender. The dilemma was also shown when the informant also repeatedly stated that $\mathrm{s} / \mathrm{he}$ did not want to just win. Motives that appear in determining cost magnitude for informants are:

a) Because motives. When participating in the tender, the informant did not want to just get a job. This is due to her/his past experience in projects that s/he has handled, in fact, incurred costs that were unplanned. This past experience is the informant's motive when determining cost magnitude.

b) In order to motives. Determination of cost magnitude in tenders by informants has a goal, namely, they do not want to even bear the loss later by forcing a low tender proposal price. In addition, the determination of the informant's cost magnitude is also based on the desire of the informant to maintain good relations with suppliers who have been helping a lot.

\section{Conclusion}

In setting the tender price, the informant means determining the cost component as something that feels complicated. This meaning arises because in determining the cost component of the informant is limited by rules that only allow direct costs only in the tender proposal. In reality, indirect costs also play a role for informants, therefore, indirect costs are the full responsibility of the informants. Then, cost magnitude is also important in determining tender prices. Informants feel a dilemma when determining cost magnitude. This meaning of dilemma arises because the informant has special considerations in determining the cost magnitude. In addition to wanting to maintain good relations with suppliers, the informants also did not want to be just from winning.

For further researchers, it is hoped that they can better understand the object of research to be studied. It would be better if the meaning of the costs in determining the tender proposal price was not only seen from one company and could add research informants. In addition, the limited time of research causes not all

Paramita, N. P. P., Sudana, I. P., Budiasih, I., \& Suprasto, H. B. (2019). Meaning of cost components and cost magnitude determining tender prices: A study on CV. RG. International Journal of Social Sciences and Humanities, 3(2), 250-260. https://doi.org/10.29332/ijssh.v3n2.324 
realities can be revealed in this study. Thus, future researchers are expected to be able to further explore other realities in order to enrich the results of the research.

Acknowledgments

The authors would like to acknowledge the editor of IJSSH for their valuable time, support, and advice. 
References

Ajzen, I. (1991). The theory of planned behavior. Organizational behavior and human decision processes, 50(2), 179-211. https://doi.org/10.1016/0749-5978(91)90020-T

Berling, P. (2008). Holding cost determination: An activity-based cost approach. International Journal of Production Economics, 112(2), 829-840. https://doi.org/10.1016/j.ijpe.2005.10.010

Datar, S. M., Rajan, M. V., Wynder, M., Maguire, W., \& Tan, R. (2013). Cost accounting: a managerial emphasis. Pearson Higher Education AU.

European Commission. Directorate-General for Employment, Industrial Relations, \& Social Affairs. Directorate V/F. (1998). Report on osteoporosis in the European Community: action for prevention. Office for Official Publications of the European Communities.

Ingenbleek, P. T. (2015). Price strategies for sustainable food products. British Food Journal, 117(2), 915-928.

Khanh, T. Q., \& Bodrogi, P. (2018). Colour preference, naturalness, vividness and colour quality metrics, Part 3: Experiments with makeup products and analysis of the complete warm white dataset. Lighting Research \& Technology, 50(2), 218-236.

Komalasari, Y., Wirajaya, I. G. A., \& Sari, M. M. R. Akuntabilitas Akuntan Perempuan-Karir Bali: Sebuah Studi Fenomenologi. Jurnal Ilmiah Akuntansi dan Bisnis, 70-85. https://doi.org/10.24843/JIAB.2019.v14.i01.p07

Latupeirissa, J. E., Marzuki, P. F., \& Wirahadikusumah, R. D. (2009). Persepsi Tentang Contingency Cost Kontraktor di Indonesia: Sebuah Survey. Jurnal Teknik Sipil Universitas Atma Jaya Yogyakarta, 7(3), 287299.

Pietkiewicz, I., \& Smith, J. A. (2014). A practical guide to using interpretative phenomenological analysis in qualitative research psychology. Psychological journal, 20(1), 7-14. https://doi.org/10.14691/CPPJ.20.1.7

Putri, Y. K. W., \& Sujana, I. K. (2018). The influence of bid-ask spread and leverage on earnings management with good corporate governance as moderating variable. International Research Journal of Management, IT and Social Sciences, 5(3), 8-21

Schutz, A. (1967). The phenomenology of the social world. Northwestern University Press.

Shinebourne, P. (2011). The Theoretical Underpinnings of Interpretative Phenomenological Analysis (IPA). Existential Analysis: Journal of the Society for Existential Analysis, 22(1).

Shrestha, P. P., Burns, L. A., \& Shields, D. R. (2013). Magnitude of construction cost and schedule overruns in public work projects. Journal of Construction Engineering, 2013. http://dx.doi.org/10.1155/2013/935978

Smith, G. E., \& Nimer, D. (2012). The Founding Principles and Strategies of Pricing. In Visionary Pricing: Reflections and Advances in Honor of Dan Nimer (pp. 13-44). Emerald Group Publishing Limited. https://doi.org/10.1108/S1069-0964(2012)0000019007

Smith, J. A. (2011). Evaluating the contribution of interpretative phenomenological analysis. Health psychology review, 5(1), 9-27. https://doi.org/10.1080/17437199.2010.510659

Smith, J. A., \& Osborn, M. (2008). Interpretative phenomenological analysis. Doing social psychology research. The British Psychological Society and Blackwell Publishing, Oxford, doi, 10, 9780470776278.

Smith, J. A., \& Osborn, M. (2015). Interpretative phenomenological analysis as a useful methodology for research on the lived experience of pain. British journal of pain,9(1), 41-42. https://doi.org/10.1177\%2F2049463714541642

Tversky, A., \& Kahneman, D. (1991). Loss aversion in riskless choice: A reference-dependent model. The quarterly journal of economics, 106(4), 1039-1061. https://doi.org/10.2307/2937956

Paramita, N. P. P., Sudana, I. P., Budiasih, I., \& Suprasto, H. B. (2019). Meaning of cost components and cost magnitude determining tender prices: A study on CV. RG. International Journal of Social Sciences and Humanities, 3(2), 250-260. https://doi.org/10.29332/ijssh.v3n2.324 


\section{Biography of Authors}

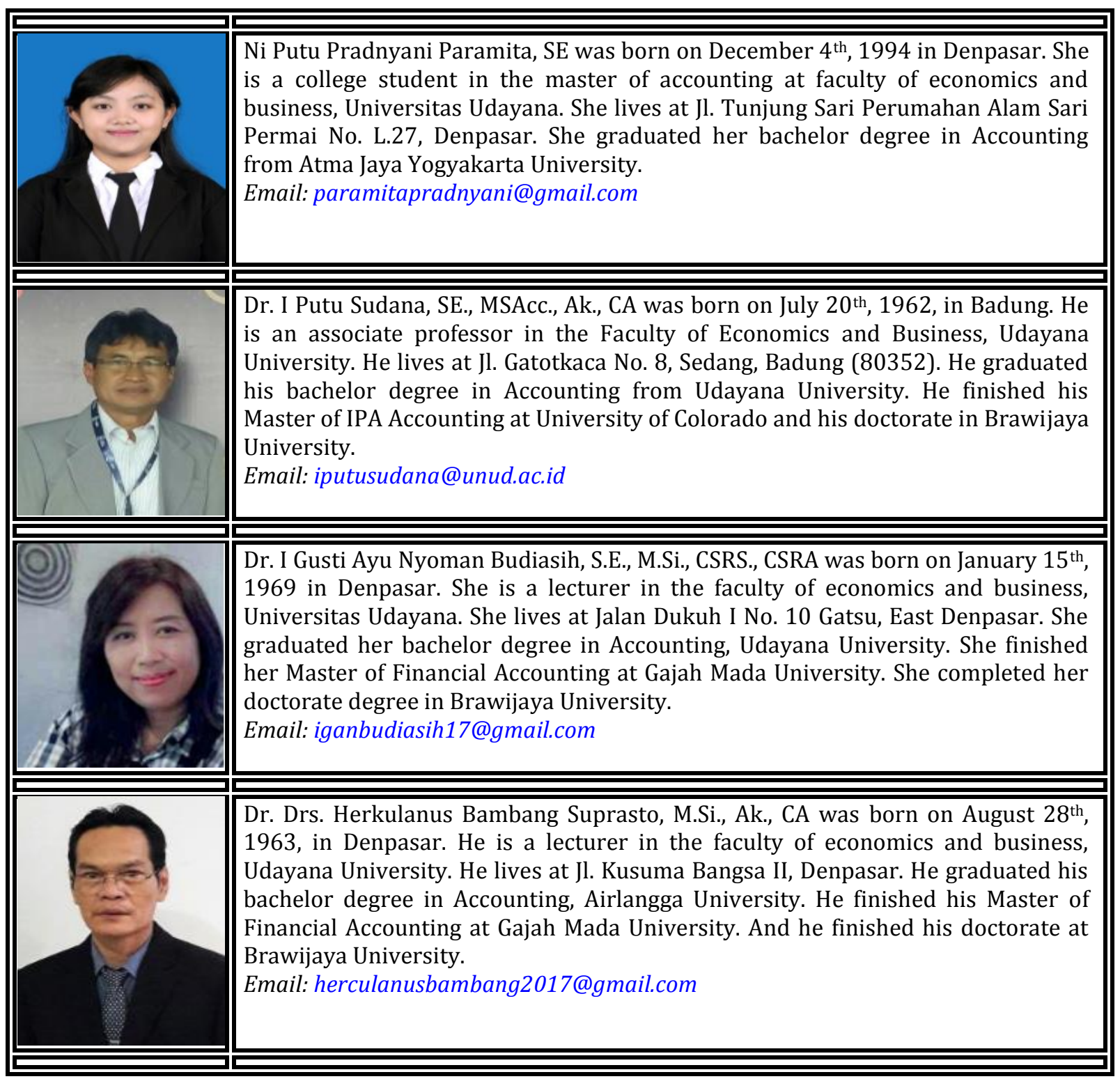

